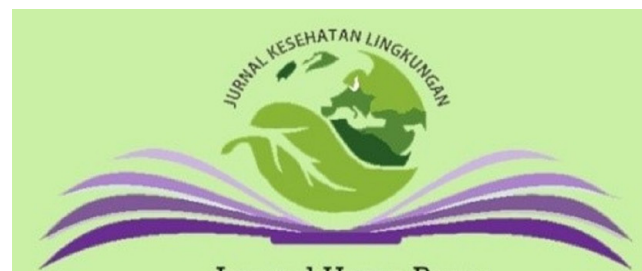

Journal Home Page:

https://e-journal.unair.ac.id/JKL

\section{Jurnal Kesehatan Lingkungan}

Vol. 14 No. 1

DOI: $10.20473 /$ jkl.vl4il.2022.55-62

ISSN: 1829 - 7285

E-ISSN: 2040 - 881X

\title{
QUALITY OF HANDWASHING IN INFORMAL WORKERS IN INDONESIA
}

Basuki Rachmat ${ }^{1 *}$, Antonius Yudi

Kristanto $^{1}$, Totih Ratna Sondari ${ }^{1}$

${ }^{1}$ National Institute of Health Research and

Development, Ministry of Health of Republic of

Indonesia, Jakarta 10560, Indonesia

Corresponding Author:

*) basukir2009@gmail.com

\section{Article Info}

Submitted

In reviewed

Accepted

Available Online

19 November 2021

21 December 2021

6 January 2021

31 January 2022

Keywords : Handwashing, Quality of handwashing, Informal workers, Formal workers

Published by Fakultas Kesehatan Masyarakat

Universitas Airlangga

\section{Abstract}

Introduction: Worker behavior of handwashing with soap in the informal sector has rarely not been studied in Indonesia. This study was conducted to determine factors related to the quality of handwashing performed by workers in the formal and informal sectors in Indonesia. Methods: The research used secondary data from Indonesia Basic Health Research. The research design was cross-sectional, and a total sample included was 421,404 workers at the productive age of 15-64 years across 34 provinces in Indonesia. The data collected included age, gender, marital status, education, place of residence, occupation, and handwashing practice. The determinants were identified using binary logistic regression. Results and Discussion: Results showed that 1.9\% of workers did not wash their hands, and $35.0 \%$ only washed their hands with water; most of them worked in the informal sector $(77.5 \%)$. Regarding the characteristics of workers, age $(O R=1.17$; 95\% CI: 1.14-1.21), gender (OR=1.23; 95\% CI: 0.93-0.99), education $(O R=2.07$; 95\% CI: 2.01-2.14), and formal workplace (OR=1.43; 95\% CI: 1.40-1.46) were mostly related to the quality of handwashing. Conclusion: The government is expected to formulate a structured policy in educating the workers, especially for male, young (15-24 years), low educated, and informal workers, about good handwashing. This study recommends that the government should use the current research findings to target proper population for the policy implementation.

\section{INTRODUCTION}

Informal workforce gives irregular income from unregistered entities. According to the Statistics Indonesia in 2019, the informal workforce consists of entrepreneurs assisted by temporary workers and families, farm/ agricultural workers, non-agricultural workers, and unpaid family labor. According to the Statistics Indonesia in 2019, 74.08 million people $(7.27 \%$ ) work in the informal sector in 2019 (1). Occupational Health Efforts (OHE) are used to develop occupational health in the informal sector in Indonesia. The implementation of OHE includes promotive, preventive, curative, and rehabilitative services. OHE is a type of community empowerment to protect informal workers from adverse impacts and free them from work-related health problems (2).

Protection from the risk of disease transmission through infected palms is by handwashing with soap in running water. According to the World Health Organization (WHO), three billion people or $40 \%$ of the world's population do not have handwashing stations with soap and water (3). Three-quarters of those who lack access to water and soap live in the world's poorest countries. According to scientific evidence and recent experience, efforts to improve hand hygiene globally can prevent approximately 165,000 deaths from diarrheal diseases each year (4). Improving hand hygiene strategies can reduce healthcare-associated infections and antimicrobial resistance (5-6).

Access to hand hygiene in public and home facilities is critical to protecting workers' health and reducing the risk of future outbreaks. The benefits of handwashing with soap (HWWS) for personal and community health are reducing $23-40 \%$ of people with diarrhea, $16-21 \%$ of people with respiratory diseases such as colds, and $58 \%$ of diarrhea cases in people with weak immunity (7). One of the efforts to improve hand hygiene is to facilitate basic access to handwashing facilities equipped with soap and water, both at home and in public facilities. According to BPS data, the population with handwashing facilities with soap in five years has increased quite well. The best increase in handwashing facilities occurred in the first three years of 2016,2017 , and 2018 at $66.28 \%, 68.16 \%$, and $78.87 \%$, respectively. Meanwhile, the growth of handwashing facilities decreased in 2019 to $76.07 \%$ and increased again in 2020 to $78.3 \%$ (8).

Even though some informal workers and their families live in urban areas, they will still be at risk of contracting the virus. The surroundings are too crowded 
and unsanitary, and thus physical distancing is hard to do. Lack of access to clean, running water and handwashing facilities restricts workers to handwash (9). Informal workers, those especially in rural areas, lack information about preventive measures e.g., handwashing with soap, as well as the virus, its symptoms, and spread. If they continue to work, they usually do not have access to Personal Protective Equipment (PPE) and adequate handwashing facilities (10). Constraints such as limited workspace in urban areas make it impossible to build handwashing facilities such as sinks, thus making informal workers handwash with little water. Even if people handwash in a shorter time but frequently, they can still maintain their hand hygiene. Handwashing with soap in clean running water is a sanitary measure to maintain the quality of hands and fingers hygiene. The duration of good handwashing with soap, according to the WHO, ranges from 20-40 seconds (6). However, the fact that hand hygiene can last than an hour is still not widely known. When bacteria and viruses land on surfaces made of cardboard, metal, and plastics, they can last for hours, even days (11).

Handwashing with soap in Indonesian population has improved in the last ten years; the results of the Basic Health Research in 2007, 2013 and 2018 showed that the proportion of proper handwashingin the Indonesian population aged 10 years and over increased from $23.2 \%$ in 2007 to $47.0 \%$ in 2013 and $49.8 \%$ in 2018 (12-14). However, the trends of handwashing with soap in informal sector workers have nationally not been informed yet. This study aimed to convey information about the quality of handwashing in informal sector workers in Indonesia using the 2018 Basic Health Research. Based on this aim, it is necessary to prove whether there is a relationship between types of workers, age, gender, marital status, education, and the quality of handwashing, and occupation.

\section{METHODS}

\section{Research Design and Data Collection}

The research used secondary data from the 2018 Basic Health Research. The Indonesian Ministry of Health through The National Institute of Research and Development (NIHRD) released the results of Basic Health Research which were collected for two months from April to May 2018 across 34 provinces. Indonesia Basic Health Research is a national-scale survey with a cross-sectional study design targeting all households in Indonesia as the study population. It used the probability proportional to size (PPS) method and the stratified multistage systematic random sampling design to determine the household samples. In the the first stage, the current research used PPS to select 30,000 primary sample units (PSU) from the 2010 Indonesian Population Census. Each PSU consists of several census blocks (BS) as census enumeration areas (EA). The second stage was the selection of BS in each selected PSU using PPS based on the estimated number of households from the 2010 Indonesian Population Census. The third stage was BPS random selection of 25 selected households based on inclusion criteria. A total of 295,720 households as many as 1,091,528 household members were successfully surveyed/visited as a sample of the 2018 Basic Health Research in 34 provinces (14). Exceptions for BS were inaccessible due to extreme geographical conditions, social unrest/conflict, and natural disasters.

Data collection in the Basic Health Research was done by trained enumerators. Previously, enumerators received training on how to use questionnaires, approach respondents, communicate effectively, and get approval from respondents. Village officers and local health workers accompanied the enumerators to visit the selected households. Before starting the interview, the enumerators asked for consent from all family members who needed to fill out a consent form. After obtaining approval, the enumerators conducted interviews with the guardians or parents (representatives of the households, e.g., older members, spouses, and the head of the household) followed by all other household members. During the interview, parents or guardians accompanied household members aged less than 15 years. Data collection was done using a structured paper-based questionnaire about household and individual levels. There are two types of Basic Health Research questionnaires in 2018, namely household questionnaires and individual questionnaires. The use of household questionnaires at the beginning of the interview, where the enumerators asked various questions about individual information in the household, access to health facilities, mental disorders in the household, and environmental health. At the same time, the use of individual questionnaires after the household questionnaire contains questions about infectious diseases, non-communicable diseases, mental health, disability, cedar, traditional health services, behavior, knowledge, and attitudes towards HIVIAIDS, maternal health, toddler health, measurement, and examination clinic. The CSPro 7.3, a census and survey processing system, was used to perform data entry (15).

\section{Data and Variable Resources}

This study further analyzed a subset of data from the 2018 Indonesia Basic Health Research. The units of analysis were 421,404 respondents who worked across 34 provinces in Indonesia and were at the productive age 
of $15-64$ years. We chose a minimum age of 15 years because the age range was categorized as teenagers in the Indonesia setting (16). Teenagers are mature in thinking and able to make decisions (17). The inclusion criteria of the respondents were Formal and informal workers. The formal workers were those who worked in state-owned enterprises, national army or police sector, regionally owned enterprises (code 3 ), or private employees (code 4). Informal workers receive irregular income from entities that are not registered while formal workers gain income from registered organizations. On the questionnaire, types of informal workers were selfemployed worker (code 5), farmer/farm laborer (code 6), fisherman (code 7), laborer/driver/housemaid (code 8), and other occupations (code 9) (14). The exclusion criteria of the respondents were individuals who did not work and finish schools. Other variables involved in the analysis were individual characteristics such as age, gender, marital status, place of residence, and education of the respondents.

\section{Statistical Analysis}

Descriptive analysis was performed to the dependent variable to describe the general characteristics of the respondents (amount, frequency, and proportion). The distribution of characteristics (respondents' age, sex, marital status, and education) was then presented in a frequency distribution table and graph. Bivariate analysis was utilized to examine the relationship of the quality of handwashing with independent variables. Variables from the bivariate model analysis that were significant at a $p$-value of $<0.2$ were included in the multivariable logistic regression model (18). Multiple logistic regression analysis in this study was conducted to determine the most correlated variables among types of workers, age, sex, marital status, place of residence and education with the quality of handwashing. Factors related to the quality of handwashing were obtained through multivariable logistic regression analysis after potential confounders were adjusted. In the final model, the independent variables were evaluated by looking at the value of the statistical significance level at $5 \%$, odds ratio (OR) and $95 \%$ of confidence interval $(\mathrm{Cl})$. Due to the complex nature of data sampling structure in the 2018 Basic Health Research, a complex data analysis was performed.

\section{Ethical Clearance and Consent}

The National Ethics Commission at the Institute for Health Research and Development, Indonesian Ministry of Health has given ethical clearance with letter number: LB.02.01/2/KE.024/2018. Before starting the data collection, the enumerators asked the respondents for written consent upon their involvement in the research regarding the confidentiality of the identity and data submitted.

\section{RESULTS}

\section{Descriptive Results}

The distribution of the socio-demographic characteristics of workers is presented in Table 1. A total of 421,404 workers of working age group (15-64 years) were included in the analysis. Most of the workers involved in this study were adults aged $35-44$ years $(26 \%)$, while regarding the representation of gender the research had more female respondents than male $(63.6 \%)$ and married respondents (82.9\%). The latest education of the workers was dominated by secondary education level $(48.6 \%)$, and some did not finish primary school $(15.5 \%)$. According to the place of residence, most of the respondents lived in urban areas $(54.1 \%)$. Based on the type of work, most of the workers worked in the informal sector $(77.5 \%)$. In this study, 8,124 workers $(1.9 \%)$ did not wash their hands, 147,398 workers $(35.0 \%)$ did good handwashing, and 265,882 (63.1\%) performed good handwashing.

Table 1. Distribution of Characteristics of Workers in Indonesia in $2018(n=421,404)$

\begin{tabular}{|c|c|c|}
\hline Individual Characteristics & $\mathbf{n}$ & $\%$ \\
\hline \multicolumn{3}{|l|}{ Age } \\
\hline 15-24 years (Ref.) & 55,724 & 13.2 \\
\hline 25-34 years & 107,995 & 25.6 \\
\hline $35-44$ years & 109,409 & 26.0 \\
\hline $45-54$ years & 91,812 & 21.8 \\
\hline $55-64$ years & 56,464 & 13.4 \\
\hline \multicolumn{3}{|l|}{ Gender } \\
\hline Man (Ref.) & 268,160 & 63.6 \\
\hline Woman & 153,244 & 36.4 \\
\hline \multicolumn{3}{|l|}{ Marital Status } \\
\hline Single (Ref.) & 72,089 & 17.1 \\
\hline Married & 349,315 & 82.9 \\
\hline \multicolumn{3}{|l|}{ Education } \\
\hline No education (Ref.) & 65,165 & 15.5 \\
\hline Primary & 101,992 & 24.2 \\
\hline Secondary & 204,707 & 48.6 \\
\hline Tertiary & 49,539 & 11.8 \\
\hline \multicolumn{3}{|l|}{ Residence } \\
\hline Urban (Ref.) & 227,806 & 54.1 \\
\hline Rural & 193,598 & 45.9 \\
\hline \multicolumn{3}{|l|}{ Occupation } \\
\hline Informal (Ref.) & 326,789 & 77.5 \\
\hline Formal & 94,615 & 22.5 \\
\hline \multicolumn{3}{|l|}{ Hand washing quality } \\
\hline Bad (Not washing hands) & 8,124 & 1.9 \\
\hline Enough (Sometimes washing hands) & 147,398 & 35.0 \\
\hline $\begin{array}{l}\text { Good (Regularly washing hands with soap } \\
\text { in clean running water) }\end{array}$ & 265,882 & 63.1 \\
\hline
\end{tabular}




\section{Bivariate Analysis}

In Table 2, the results of the bivariate logistic regression test show the relationship of the quality of handwashing with demographic characteristics and employment status. Viewed by age group, older participants (aged 25 years and over) were more likely to perform good handwashing. Workers aged 55-64 years were significantly associated with good handwashing $(\mathrm{OR}=0.93 ; 95 \% \mathrm{Cl}: 0.91-0.95)$. According to gender, female workers were significantly associated with good handwashing than males $(\mathrm{OR}=1.21 ; 95 \% \mathrm{Cl}: 1.20-1.23)$. Workers who were married were more likely to perform good handwashing than single ones (unmarried).

Table 2. Bivariate Analysis of Variables Related to the Quality of Handwashing Among Workers in Indonesia $(n=421,404)$

\begin{tabular}{lccccc}
\hline \multirow{2}{*}{ Variable } & \multicolumn{5}{c}{ Quality Hand Wash } \\
\cline { 2 - 6 } & Yes & No & OR & $\mathbf{9 5 \%}$ CI & p \\
\hline Age & & & & & \\
15-24 years (Ref.) & 63.2 & 36.8 & & & \\
25-34 years & 63.2 & 36.8 & 1.00 & $0.98-1.02$ & 0.83 \\
35-44 years & 63.5 & 36.5 & 1.01 & $0.99-1.04$ & 0.19 \\
$\quad$ 45-54 years & 63.5 & 36.5 & 1.01 & $0.99-104$ & 0.23 \\
$\quad$ 55-64 years & 61.4 & 38.6 & 0.93 & $0.91-0.95$ & 0.00 \\
\hline Gender & & & & & \\
$\quad$ Man (Ref.) & 61.5 & 38.5 & & & \\
$\quad$ Woman & 65.9 & 34.1 & 1.21 & $1.20-1.23$ & 0.000 \\
\hline Marital Status & & & & & \\
$\quad$ Single (Ref.) & 63.3 & 36.7 & & & \\
$\quad$ Married & 63.1 & 36.9 & 0.99 & $0.97-1.01$ & 0.266 \\
\hline Education & & & & & \\
$\quad$ No education (Ref.) & 52.3 & 47.7 & & & \\
$\quad$ Primary & 57.7 & 42.3 & 1.24 & $1.22-1.27$ & 0.000 \\
$\quad$ Secondary & 65.8 & 34.2 & 1.75 & $1.72-1.78$ & 0.000 \\
$\quad$ Tertiary & 77.5 & 22.5 & 3.13 & $3.05-3.22$ & 0.000 \\
\hline Residence & & & & & \\
$\quad$ Urban (Ref.) & 71.5 & 28.5 & & & \\
$\quad$ Rural & 53.2 & 46.8 & 0.45 & $0.45-0.46$ & 0.000 \\
\hline Occupation & & & & & \\
$\quad$ Informal (Ref.) & 59.6 & 40.4 & & & \\
$\quad$ Formal & 75.2 & 24.8 & 2.05 & $2.02-2.09$ & 0.000 \\
\hline$\quad$ & & & & &
\end{tabular}

Education level was significantly related to the quality of handwashing with soap. The higher the worker education level, the better the possibility of handwashing. Workers who attended primary education $(\mathrm{OR}=1.24$; $95 \% \mathrm{Cl}: 1.22-1.27)$, intermediate education (OR = $1.75 ; 95 \% \mathrm{Cl}: 1.72-1.78)$, and high education (OR = 3.13; $95 \% \mathrm{Cl}: 3.05-3.22$ ) were more likely to perform good handwashing compared to those who did not attend school. The place of residence was significantly related to the quality of handwashing. Workers who lived in urban areas were more likely to perform good handwashing than those in rural areas (OR $=0.451 ; 95 \%$ $\mathrm{Cl}$ : 0.445-0.457). Occupation was significantly related to the quality of handwashing as well. Formal workers were more likely to perform good handwashing than informal workers (OR $=2.05 ; 95 \% \mathrm{Cl}: 2.02-2.09)$.

\section{Multivariate Analysis}

The binary logistic regression test results on factors related to the quality of handwashing in workers are depicted in Table 3. This statistical test can determine the determinants of knowledge about the quality of handwashing among workers in Indonesia. For reference, the selected category is "no handwashing". Table 4 illustrates that workers in the older age group had a more significant opportunity to wash their hands than those in the age of 15-24 years as a reference. For example, workers aged 55-64 years had a 1.17 times chance of washing their hands compared to workers aged $15-24$ years $(\mathrm{OR}=1.17 ; 95 \% \mathrm{Cl}: 1.14-1.21)$. By gender, it appeared that female workers were more likely to perform good handwashing than male workers. Female workers were 1.23 time more likely to practice good handwashing than male workers $(\mathrm{OR}=1.23 ; 95 \%$ Cl: $0.93-0.99)$.

Table 3. Analysis of Multivariate Odds Ratio (OR) Factors Related to the Quality of Handwashing Among Workers in Indonesia in $2018(n=421,404)$

\begin{tabular}{|c|c|c|c|c|c|}
\hline \multirow{2}{*}{ Variable } & \multicolumn{5}{|c|}{ Quality Hand Wash } \\
\hline & Yes & No & OR & $95 \%$ CI & $\mathbf{p}$ \\
\hline \multicolumn{6}{|l|}{ Age } \\
\hline 15-24 years (Ref.) & 63.2 & 36.8 & & & \\
\hline 25-34 years & 63.2 & 36.8 & 0.96 & $0.94-0.99$ & 0.006 \\
\hline $35-44$ years & 63.5 & 36.5 & 1.06 & $1.03-1.08$ & 0.000 \\
\hline 45-54 years & 63.5 & 36.5 & 1.13 & $1.10-1.16$ & 0.000 \\
\hline $55-64$ years & 61.4 & 38.6 & 1.17 & $1.14-1.21$ & 0.000 \\
\hline \multicolumn{6}{|l|}{ Gender } \\
\hline Man (Ref.) & 61.5 & 38.5 & & & \\
\hline Woman & 65.9 & 34.1 & 1.23 & $1.21-1.25$ & 0.000 \\
\hline \multicolumn{6}{|l|}{ Marital Status } \\
\hline Single (Ref.) & 63.3 & 36.7 & & & \\
\hline Married & 63.1 & 36.9 & 1.11 & $1.09-1.14$ & 0.000 \\
\hline \multicolumn{6}{|l|}{$\overline{\text { Education }}$} \\
\hline No education (Ref.) & 52.3 & 47.7 & & & \\
\hline Primary & 57.7 & 42.3 & 1.24 & $1.21-1.26$ & 0.000 \\
\hline Secondary & 65.8 & 34.2 & 1.51 & $1.48-1.54$ & 0.000 \\
\hline Tertiary & 77.5 & 22.5 & 2.07 & $2.01-2.14$ & 0.000 \\
\hline \multicolumn{6}{|l|}{ Residence } \\
\hline Urban (Ref.) & 71.5 & 28.5 & & & \\
\hline Rural & 53.2 & 46.8 & 0.53 & $0.52-0.53$ & 0.000 \\
\hline \multicolumn{6}{|l|}{ Occupation } \\
\hline Informal (Ref.) & 59.6 & 40.4 & & & \\
\hline Formal & 75.2 & 24.8 & 1.43 & $1.40-1.46$ & 0.000 \\
\hline
\end{tabular}

Workers with married status were 1.11 times more likely to practice good handwashing than those who were unmarried yet or never married $(O R=1.11 ; 95 \%$ $\mathrm{Cl}: 1.09$ - 1.14). Workers with tertiary education were 2.07 times more likely to practice good handwashing than those who never attended school (OR $=2.07 ; 95 \%$ $\mathrm{Cl}: 2.01-2.14)$. Based on the housing criteria, workers from rural areas were 0.53 more likely to practice good handwashing than those living in urban areas $(O R=0.53$; $95 \% \mathrm{Cl}: 0.52-0.53)$. Workers in the formal sector were 
1.43 times more likely to practice good handwashing than those in the informal sector $(\mathrm{OR}=1.43 ; 95 \% \mathrm{Cl}$ : $1.40-1.46)$.

\section{DISCUSSION}

Good handwashing is washing hands with soap in running water to rinse the foam at the indefinite duration. Referring to the Joint Monitoring Program (JMP), the indicators for good handwashing practice is divided into three. First, handwashing facilities are available at home, and they provide soap and water. Second, limited handwashing facilities are available at home without soap or water. Third, none of handwashing facilities available at home is referred to no service. However, this definition is limited to households, technically not non-household groups (19). Washing hands properly can help prevent the spread and eliminate viruses on the surface of the hands that emerge after coughing, sneezing, and touching objects containing infectious pathogen. Handwashing also reduces the rate of respiratory infections and prevent them to enter the body or transmit (20-23).

Results showed that $77.5 \%$ of the respondents worked in the informal sector. Of the workers, $63.1 \%$ washed their hands properly, and $1.9 \%$ of workers did not. From the analysis results, workers in the formal sector were 1.43 times more likely to practice good handwashing than those in the informal sector, possibly because of available handwashing facilities such as clean water sources, permanent handwashing facilities, running water, soap, and permanent toilets which are more likely available in the formal sector (24-26). According to the Situational Analysis Report from UNICEF, speaking public handwashing facilities e.g., terminals/stations and public transport, $56 \%$ of them have limited access, and $30 \%$ of them have no access. In traditional markets, parks, places of worship, public service, and others, $26 \%$ of them have limited access, and $44 \%$ of them have no access. Moreover, limited handwashing facilities are available in $99.29 \%$ of healthcare centers (27). Thus, it is necessary to improve basic handwashing facilities in public.

This current study showed female workers were more likely to practice good handwashing than male workers. These results are consistent with studies in the United States and Korea which found that female participants washed their hands significantly more than male participants (28-32). Women have high commitment to hand hygiene, and in general, this attitude is an acceptable behavior (33-35). Besides, men tend to ignore hand hygiene practices, especially in hurry when going to the bathroom alone (29). Compliance rates with handwashing in women are generally better than men, and women may find it easier to follow hand hygiene guidelines from promotional materials (36-37). Thus, the effect of the promotion media on handwashing practice on women may be more potential than men.

The analysis results proved that older workers had a 1.17 times greater chance of washing their hands than younger workers (15-24 years). This finding is consistent with the results of several studies which stated that older age is associated with better perceptions of hand hygiene practices (38-39). However, these results are inconsistent with studies in Cameroon (40) and Bangladesh (41), where older age is significantly associated with lower mean scores of knowledge. These studies showed that older people have lower scores in knowledge about hand hygiene and handwashing practice compared to younger counterparts. Generally, older adults have fewer opportunities to receive education on hand hygiene than younger ones (42). Thus, education on hand hygiene or exposure to hand hygiene campaigns for older adults can increase their awareness of hand hygiene.

Workers with higher education were 2.07 times more likely to practice good handwashing compared to those who never attended schools. In general, workers with higher education had a work environment that has more accessible handwashing facilities and infrastructure. Individuals who did not attend school had fewer opportunities to receive education on hand hygiene or be exposed to hand hygiene campaigns compared to those with higher education levels. Access to education on proper handwashing is likely to increase awareness of handwashing.

Socialization and education on informal workers might increase awareness of microbial transmission through hands, emphasize the importance of hand hygiene and its indications, and demonstrate the proper handwashing procedure. The Information Education Communication (IEC) products, such as IEC print media, IEC social media, and IEC electronic media as sources of information can be used to promote good handwashing behavior (43). Primary healthcare centers need to conduct counseling related to good handwashing in public facilities (25). Good cooperation with social institutions/institutions related to handwashing programs needs to be encouraged (44). Involvement of health cadres in education and community empowerment is related to proper handwashing programs. Permanent handwashing facilities with the availability of soap and clean water should be provided around public facilities (schools, markets, transportation places, houses of worship, recreation areas, commercial buildings, and others) (45-46). 
To improve the quality of hand washing, increasing access to water supply and physical infrastructure, soap, alcohol-based hand rub, and affordable cleaning equipment is another effort. In addition, it is necessary to change individual behavior since handwashing should be an integral part of our daily life. Some common obstacles are improper sink placement, damaged sink, perceived time; skin irritation; and workflows that do not provide workers opportunities to practice handwashing. Besides, hand hygiene is also one of the most cost-effective ways to prevent the spread of infectious diseases. According to WHO, improving hand hygiene policies can result in savings in health expenditures of up to 15 times.

The limitation of this study is that the questionnaire of Indonesia Basic Health Research did not address the adequate time and procedures for good handwashing which are supposed to accord with the WHO's recommendations. In addition, the questionnaire also does not have questions related to handwashing facilities at work, in public places, and residential areas, and thus this study does not describe the availability of facilities at work and home.

\section{CONCLUSION}

Out of $77.5 \%$ informal workers, $1.9 \%$ did not wash hands after doing activities at work; $35.0 \%$ did handwashing in water, and $63.1 \%$ did handwashing with soap in running water. The results showed that female workers are more likely to apply good handwashing than male workers. Highly educated workers are more likely to practice good handwashing than workers with low education. Formal workers are more likely to practice good handwashing than informal workers. The workers in the informal sector cannot access adequate public handwashing facilities. Support from various parties is needed to facilitate adequate basic access to public handwashing facilities and increase knowledge about good handwashing, especially in young (15-24 years), low educated, male informal workers. This study recommends that the government should focus on the current research findings to target a policy setting.

\section{REFERENCES}

1. Central Statistic Agency of Indonesia. February 2019: Open Unemployment Rate (TPT) of 5.01 Percent. Jakarta: Central Statistic Agency of Indonesia; 2019. https://www.bps.go.id/

2. Yusida $H$, Suwandi $T$, Yusuf $A$, Sholihah $Q$. Kepedulian Aktif untuk K3 Sektor Informal. Banjarmasin: Banjarmasin Post Group; 2017. http:// eprints.ners.unair.ac.id/643/

3. World Health Organization and the United Nations
Children's Fund. Hand Hygiene for All. Geneva: United Nations Children's Fund; 2020. 1-12 p. https://www.unicef.org/reports/hand-hygiene-forall-2020

4. Prüss-Ustün $\mathrm{A}$, Wolf $\mathrm{J}$, Bartram $\mathrm{J}$, Clasen $\mathrm{T}$, Cumming $\mathrm{O}$, Freeman $\mathrm{MC}$, et al. Burden of Disease from Inadequate Water, Sanitation and Hygiene for Selected Adverse Health Outcomes: An Updated Analysis With A Focus On Low- and Middle-Income Countries. Int J Hyg Environ Health. 2019;222(5):765-777. https://doi.org/10.1016/j. ijheh.2019.05.004

5. Luangasanatip N, Hongsuwan M, Limmathurotsakul D, Lubell Y, Lee AS, Harbarth S, et al. Comparative Efficacy of Interventions to Promote Hand Hygiene in Hospital: Systematic Review and Network MetaAnalysis. BMJ. 2015;351(h3728):1-14. https://doi. org/10.1136/bmj.h3728

6. World Heatlh Organization. Evidence of Hand Hygiene as the Building Block for Infection Prevention and Control an Extract from the Systematic Literature Reviews Undertaken as the Background for the WHO Guidelines on Core Components. Switzerland: World Heatlh Organization; 2017. 1-30 p. https://apps.who.int/iris/

7. Centers for Disease Control and Prevention. Handwashing: Clean Hands Save Lives. New York: U.S. Department of Health \& Human Services; 2020. https://www.cdc.gov/handwashing/whyhandwashing.html

8. Central Statistic Agency of Indonesia. Proportion of Households Owning Handwashing Facilities with Soap and Water by Province (Percent), 2018-2020. Jakarta: Central Statistic Agency of Indonesia; 2021. https://www.bps.go.id/

9. International Labour Organization. Improving Occupational Safety, Health, and Environment in the Informal Footwear Sector. Jakarta: International Labour Organization; 2003. 1-36 p. http://www.llo.org/jakarta/whatwedo/publications/ WCMS 120633/lang--en/index.htm

10. International Labour Organization. The Covid19 Crisis and the Informal Sector: Immediate Responses and Policy Challenges. Jakarta: International Labour Organization; 2020. https:// www.ilo.org/jakarta/whatwedo/publications/ WCMS 744424/lang--en/index.htm

11. Jayaweera M, Perera H, Gunawardana B, Manatunge J. Transmission of Covid19 Virus by Droplets and Aerosols: A Critical Review on the Unresolved Dichotomy. Envronmental Res. 2020;188(1):1-18. $\quad$ https://doi.org/10.1016/j. envres.2020.109819

12. Ministry of Health of Republic Indonesia. Report of Basic Health Research year 2007. Jakarta: National Institute of Health Research and Development Ministry of Health; 2008. http://labdata.litbang. kemkes.go.id

13. Ministry of Health of Republic Indonesia. Report of Basic Health Research year 2013. Jakarta: National Institute of Health Research and Development Ministry of Health; 2014. http://labdata.litbang. kemkes.go.id 
14. Ministry of Health of Republic Indonesia. Report of Basic Health Research year 2018. Jakarta: National Institute of Health Research and Development Ministry of Health; 2019. http://labdata.litbang. kemkes.go.id

15. United States Census Bureau. CSPro Training Manual. United States: United States Census Bureau; 2018. 1-23 p. https://www.census.gov/ population/international/

16. Ministry of Health of Republic Indonesia. Strategic Planning of Ministry of Health 2015-2019. Jakarta: Ministry of Health of Republic Indonesia; 2013. http:// ppid.kemkes.go.id/uploads/img_5cd07f7e6d039. pdf

17. Santrock JW. Life-Span Development. $13^{\text {th }}$ ed. Jakarta: Erlangga; 2012.

18. Wang H, Peng J, Wang B, Lu X, Zheng JZ, Wang K, et al. Inconsistency between Univariate and Multiple Logistic Regressions. Shanghai Arch Psychiatry. 2017;29(2):124-128. https://doi.org/10.11919/j. issn.1002-0829.217031

19. World Health Organization and the United Nations Children's Fund. Progress on Household Drinking Water, Sanitation and Hygiene 2000-2020: Five Years into the SDGs. Geneva: World Health Organization; 2021. 1-162 p. https://apps.who.int/ iris/handle/10665/345081

20. Lulla M, Rutkovskis A, Slavinska A, Vilde A, Gromova A, Ivanovs $M$, et al. Hand-Washing Video Dataset Annotated According to the World Health Organization's Hand-Washing Guidelines. Data. 2021;6(4):1-6. https://doi.org/10.3390/ data6040038

21. Park S. A Study on the Perception of Hand Washing and Health Status in Korean Adults. Medicine. 2021;100(3):e24421.

MD.0000000000024421

22. Smith L, Butler L, Tully MA, Jacob L, BarnettY, LópezSánchez GF, et al. Hand-Washing Practices Among Adolescents Aged 12-15 Years from 80 Countries. Int J Environ Res Public Health. 2021;18(1):1-15. https://doi.org/10.3390/ijerph18010138

23. Gedamu H, Wgiorgis T, Tesfa G, Tafere $Y$, Genet M. Hand Washing Practice Among Health Care Workers in Ethiopia: Systemic Review and MetaAnalysis, 2020. Heliyon. 2021;7(5):e06972. http:// dx.doi.org/10.1016/j.heliyon.2021.e06972

24. Sondari TR, Rachmat B, Suudi A, Widjiastuti B, Ida. Assessment of Facilities, Knowledge and Counseling on Handwashing of Elementary School Students in the District of North Bogor. $J$ Ecophysiol Occup Heal. 2020;20(2):13-20. https:/l doi.org/10.18311/JEOH/2020/25275

25. World Health Organization and the United Nations Children's Fund. WASH in Health Care Facilities: Global Baseline Report 2019. Geneva: World Health Organization; 2019. 132 p. https://www.who. int/publications/i/item/9789241515504

26. Kurniawan MF. Penetapan Kelas Standar Pelayanan JKN sebagai Amanah UU SJSN. Indonesia. Yogyakarta: Center of Health Policy and Management of UGM; 2019. https:// kebijakankesehatanindonesia.net/
27. Ministry of Health of Republic of Indonesia and the United Nations Children's Fund. GERMAS Action Plan Through Five (5) STBM Pillars, Especially Pillar 2 Washing Hands with Soap (CTPS). Jakarta: Ministry of Health of Republic of Indonesia; 2021.

28. Okello E, Kapiga S, Grosskurth H, Makata K, McHaro O, Kinungh'l S, et al. Factors Perceived to Facilitate or Hinder Handwashing Among Primary Students: A Qualitative Assessment of the Mikono Safi Intervention Schools in NW Tanzania. BMJ Open. 2019;9(11):1-10. https://doi.org/10.1136/ bmjopen-2019-030947

29. Suen LKP, So ZYY, Yeung SKW, Lo KYK, Lam SC. Epidemiological Investigation on Hand Hygiene Knowledge and Behaviour: A Cross-Sectional Study on Gender Disparity. BMC Public Health. 2019;(16):401. https://doi.org/10.1186/s12889-0196705-5

30. Berry TD, Mitteer DR, Fournier AK. Examining HandWashing Rates and Durations in Public Restrooms: A Study of Gender Differences Via Personal, Environmental, and Behavioral Determinants. Environ Behav. 2015;47(8):923-944. https://doi. org/10.1177/0013916514527590

31. White $\mathrm{S}$, Thorseth AH, Dreibelbis R, Curtis V. The DeterminantsofHandwashingBehaviourinDomestic Settings: An Integrative Systematic Review. Int J Hyg Environ Health. 2020;227(1):113512. https:// doi.org/10.1016/j.ijheh.2020.113512

32. Qazi U, Anwar S. Hand Washing Behavior Change Effect of Community-Based Hygiene and Sanitation Intervention in Low Resource Setting. J Public Health (Oxf). 2021;43(2):381-384. https://doi. org/10.1093/PUBMED/FDZ130

33. World Bank. Mainstreaming Gender in Water and Sanitation: Gender in Water and Sanitation. Washington: Water and Santation Program; 2010. https://www.wsp.org/sites/wsp.org/files/ publications/WSP-gender-water-sanitation.pdf

34. Prasetyo DD, Astini FN, Fillaili R, Widjanarko $H$. Gender and Social Inclusion (GESI) Contextual Analysis/ Formative Research for the Plans Water for Women Project in Indonesia Gender and Social Inclusion (GESI) Contextual Analysis/ Formative Research for the Plan's Water for Women Indonesia. SMERU Res Inst. 2019;1(1). https://smeru.or.id/ en/content/gender-and-social-inclusion-gesicontextual-analysisformative-research-plan'swater-women

35. Johnson HD, Sholcosky D, Gabello K, Ragni $\mathrm{R}$, Ogonosky N. Sex Differences in Public Restroom Handwashing Behavior Associated with Visual Behavior Prompts. Percept Mot Skills. 2003;97(3):805-810. $\quad$ https://doi.org/10.2466/ pms.2003.97.3.805

36. Lindahl L, An MH. Social Proximity in Early Mother-Infant Interactions: Implications for Gender Differences?. Early Dev Parent. 1997;6(2):83-88. $\quad$ https://doi.org/10.1002/ (SICI)1099-0917(199706)6:2\%3C83::AIDEDP146\%3E3.0.CO:2-K

37. Cerezo MA, Sierra-García P, Pons-Salvador G, Trenado RM. Parental and Infant Gender Factors 
in Parent-Infant Interaction: State-Space Dynamic Analysis. Front Psychol. 2017;8(1):1724. https:// doi.org/10.3389/fpsyg.2017.01724

38. Burnett E. Perceptions, Attitudes, and Behavior Towards Patient Hand Hygiene. Am J Infect Control. 2009;37(8):638-642. https://doi.org/10.1016/j. ajic. 2009.04 .281

39. Oh HS. Knowledge, Perceptions, and Self-Reported Performance of Hand Hygiene Among Registered Nurses at Community-Based Hospitals in the Republic of Korea: A Cross-Sectional Multi-Center Study. J Prev Med Public Heal. 2018;51(3):121129. https://doi.org/10.3961/jpmph. 17.188

40. Teumta GMM, Niba LL, Ncheuveu NT, Ghumbemsitia MT, Itor POB, Chongwain $\mathrm{P}$, et al. An InstitutionBased Assessment of Students' Hand Washing Behavior. Biomed Res Int.2019;2019(7178645):1-8. https://doi.org/10.1155/2019/7178645

41. Sultana M, Alam Mahumud R, Razzaque Sarker A, Mahmud Hossain S. Hand Hygiene Knowledge and Practice Among University Students: Evidence from Private Universities of Bangladesh. Risk Manag Healthc Policy. 2016;9(1):13-20. https:// doi.org/10.2147/RMHP.S98311
42. Yang J, Park EC, Lee SA, Lee SG. Associations Between Hand Hygiene Education and SelfReported Hand-Washing Behaviors Among Korean Adults During MERS-CoV Outbreak. Heal Educ Behav. 2019;46(1):157-164. https://doi. org/10.1177/1090198118783829

43. Karnik K, Larivee C, Jha S, Narain JP. Information, Education and Communication: A Guide for AIDS Programme Managers. Geneva: World Health Organization; 2000. https://apps.who.int/iris/

44. Kumwenda S. Challenges to Hygiene Improvement in Developing Countries. The Relevance of Hygiene to Health in Developing Countries. IntechOpen. 2019;1(1):1-10. intechopen.80355

45. The United Nations Children's Fund. Handwashing Stations and Supplies for the Covid19 Response. Geneva: UNICEF Fact Sheet; 2020. https://www. unicef.org/documents/handwashing-stations-andsupplies-covid-19-response

46. WaterAid. Technical Guide for Handwashing Facilities in Public Places and Buildings. Canberra: WaterAid; 2020. https://washmatters.wateraid. org/publications/technical-guide-for-handwashingfacilities-in-public-places-and-buildings 